\title{
DO STRATEGIC ALLIANCES, ACQUISITIONS, AND R\&D INVESTMENTS ACT AS COMPLEMENTS OR SUBSTITUTES?
}

\author{
Aleksey MARTYNOV \\ University of Houston Clear Lake, Houston, Texas United States \\ e-mail: martynov@uhcl.edu
}

\begin{abstract}
This paper studies possible complementarities and substitution effects between such strategic choices as alliances, acquisitions and internal R\&D investments. The findings indicate that a firm's absorptive capacity affects the presence of complementarities and substitution effects among those strategic choices. Firms with high absorptive capacity exhibit substitution effects between alliances and acquisitions and between alliances and internal R\&D investments. Firms with high absorptive capacity also exhibit complementarities between acquisitions and additional R\&D investments. These results were obtained from panel data of large and medium U.S. companies spanning the years 19982009. The results are robust to the use of different measures of performance: profitability, market-tobook value, and sales growth. This paper contributes to our understanding of the role of absorptive capacity for the optimal choice of inter-organizational strategy vs. greater internal R\&D investments.
\end{abstract}

Keywords: alliances, acquisitions, R\&D investments, absorptive capacity, firm performance, panel data.

\section{Introduction}

This paper uses the resource-based view of alliances, acquisitions, and $R \& D$ investments [1, 7 and 28] to predict joint performance implications of (1) simultaneous alliances and acquisitions, (2) simultaneous alliances and internal R\&D investments, and (3) simultaneous acquisitions and internal R\&D investments. I argue that performance effects of alliances, acquisitions, and internal $\mathrm{R} \& \mathrm{D}$ investments will depend on the firm's absorptive capacity [4]. High absorptive capacity may enable firms to extract greater value from alliances and acquisitions since such firms are likely to learn well. Meanwhile, firms may find it difficult to develop strong alliance capabilities and strong acquisition capabilities at the same time because alliances and acquisitions may involve different processes and may lead to the creation of separate alliancing and acquisition functions [9, 14]. I argue that firms with high absorptive capacity will improve their performance if they concentrate on one specific form of inter-firm strategy (either alliances or acquisitions) since learning and integrating knowledge from alliances and acquisitions is likely to require different capabilities. This logic suggests that such firms will benefit from specializing in either alliances or acquisitions and that alliances and acquisitions will act as substitutes for such firms, negatively affecting each other's performance implications.

A similar logic applies to alliances and internal R\&D investments. I argue that firms with high absorptive capacity will benefit from either more alliances or greater internal R\&D but not both (substitution effect). Finally, I argue that high-absorptive-capacity firms will benefit from simultaneous acquisitions and greater internal R\&D (complementarity effect).

I test these ideas on a panel of U.S. firms from the S\&P 500 (large cap) and S\&P 400 (medium cap) indices spanning the years 1998-2009. Conceptually, the findings contribute to the development of the theory of strategic alliances and acquisitions by showing the role of absorptive capacity in joint performance effects of these two governance choice options. These results also provide evidence that R\&D investments do not always help firms extract greater value from alliances. This finding shows that high levels of R\&D investments may reverse the expected positive effect of strategic alliances on firm performance. Finally, the results of this study show that R\&D and acquisitions act as complements. These results are robust to different measures of performance: profitability, market valuation, and growth. I discuss the implications of the results and the assumptions made in this study. I also dis- 
cuss the possible ways to relax these assumptions which open up opportunities for further research in this area.

\section{Theory and hypotheses}

Strategic alliances and acquisitions may help the focal firm gain access to other companies' resources and capabilities [5, 24, and 17]. According to the resource-based view (RBV) of alliances $[25,6$, and 21], alliances with partners that offer complementary resources may give competitive advantage to the focal firm because such alliances may create unique and difficult-to-copy resource combinations. Similarly, acquiring companies possessing related or complementary resources or capabilities may create competitive advantage and translate into higher performance [29, 17].

Alliances and acquisitions are different methods of combining the resources and capabilities of two or more firms. Furthermore, alliances and acquisitions are not always interchangeable: each of these methods of combining resources and capabilities has its own logic. According to Dyer, Kale, and Singh [9], alliances are more likely to succeed when the resources in question are intangible, uncertainty is high, and competition for resources is low. Acquisitions are more likely to succeed when the resources in question are tangible, uncertainty is low, and competition for resources is high.

Firms differ in their absorptive capacity $[4,20]$. Absorptive capacity refers to the ability of firms to "recognize the value of new information, assimilate it, and apply it to commercial ends." [4, p.128]. When firms enter alliances of make acquisitions, they may seek to gain or access new knowledge or more tangible resources such as land, plant, and equipment. In addition, firms may seek to access specific capabilities that their potential partners or targets have, such as manufacturing, marketing, or logistics capabilities. Firms with low absorptive capacity are unlikely to engage in alliances or make acquisitions that would require the focal firm to learn from its partner or target. By definition, low absorptive capacity will prevent such firms from properly integrating the knowledge that such partners or targets have and commercializing it.
Firms with high absorptive capacity are more capable of evaluating and integrating knowledge-rich partners or targets. However, evaluating the knowledge of potential alliance partners and evaluating the knowledge of potential acquisition targets may require different organizational capabilities. Alliances may be less 'final' than acquisitions. If it turns out that the initial evaluation of the partners' knowledge was inaccurate, an alliance can be dissolved relatively easily, especially if no equity investments were made. On the other hand, an acquisition can be difficult to reverse because the acquiring firm usually incurs substantial losses when selling a previously acquired target [2]. Acquisitions of knowledge-rich companies are more likely to be successful if the knowledge is codified or patented. Acquiring companies with mainly tacit knowledge is risky because the employees who possess the tacit knowledge can quit after the acquisition, leaving the acquirer with a collection of tangible resources of relatively little value [9]. Such companies may make better alliance partners than acquisition targets.

The logic above suggests that it may be difficult for high-absorptive-capacity firms to develop equal expertise in allying with and acquiring other companies. Firms with high absorptive capacity may perform better if they concentrate on one method of accessing other companies' knowledge: either alliances or acquisitions. Attempts to pursue both alliances and acquisitions simultaneously may result in lower alliancing and acquisition capabilities, which will translate in less appropriate selection of partners or targets, less skillful integration of knowledge, and as a result, lower performance of the focal firm. Based on this logic, I formulate the following hypothesis:

Hypothesis 1: For firms with high absorptive capacity, there will be a negative interaction between alliances and acquisitions in their joint effect on firm performance.

R\&D investments are likely to be positively associated with greater absorptive capacity of the firm [4, 33]. This property of $R \& D$ may have positive performance implications if greater absorptive capacity allows the focal firm to evaluate and assimilate knowledge that its alliance partners have. On the 
other hand, greater R\&D investments are likely to result in a greater stock of the firm's own knowledge. High-absorptive-capacity firms are more likely to form alliances with knowledge-rich companies than low-R\&D companies. Such knowledge-rich partners are also likely to make significant investments in $R \& D$ and have high absorptive capacity; they may also seek to learn the focal firm's knowledge when they enter the alliance. When each partner in an alliance is trying to learn the knowledge that the other partners have, a learning race may ensue [16]. The winner in such a learning race is difficult to predict in advance but each partner may emphasize private benefits at the expense of common benefits [16]. This might result in lower-thanexpected or even negative performance benefits of the alliance for each partner because the partners will be racing to learn from each other at the expense of collaboration and joint value creation.

Strategic alliances may act as a substitute for the firm's own R\&D investments. Internal $R \& D$ and partnering with another company may be alternative ways of achieving the same goal. When a firm does its own $R \& D$, it has full control over the process and the probability of unwanted knowledge leaks is relatively low. When partnering with another company, the focal firm has less control over the process and the probability of unwanted knowledge leaks is higher. The focal firm may find that its valuable knowledge resulting from its own R\&D is appropriated by its alliance partner(s). A low-R\&D firm may ally with a high-R\&D company to gain access to the knowledge of the high-R\&D company without actually learning that knowledge. This could be done via any type of alliance, e.g. R\&D alliance, manufacturing alliance, marketing alliance, etc. For example, Disney in its alliance with Hewlett-Packard did not aim to acquire the technological knowledge of HP. Disney's goal was to access the fruits of that knowledge which manifested itself in HP's technological capabilities. Disney was able to benefit from HP's R\&D investments without doing its own R\&D in the same technological area. It is possible that Disney may have learned more from HP if Disney itself had done R\&D in computer technology. However, the cost of that $R \& D$ may have been higher than the value of additional knowledge that Disney might have learned.

Firms with greater innovative performance experience lower gains in financial performance from alliance portfolios [19]. This result and the reasoning above suggest that $R \& D$ investments may act as a substitute for strategic alliances for highabsorptive-capacity firms. Such firms may find it beneficial to invest in additional internal $R \& D$ or engage in strategic alliances but not both. This logic is confirmed by the finding that combining internal exploration (e.g. R\&D investments) and external exploration (e.g. alliances) leads to lower firm performance [30]. This allows me to formulate the following hypothesis:

Hypothesis 2: For firms with high absorptive capacity, there will be a negative interaction between alliances and $R \& D$ investments in their joint effect on firm performance.

Companies that possess valuable technologies, knowledge, or patents are more likely to be acquired than other firms [12]. Based on my previous arguments, I suggest that the acquiring firms are likely to be firms with significant absorptive capacity. The acquiring firm needs significant knowledge to be able to evaluate a knowledge-rich target. Integration and assimilation of knowledge held by the target is also likely to require significant own knowledge. Cassiman and Veugelers [3] found that doing internal R\&D and acquiring technology from other firms simultaneously increased sales from new products but only for firms that had high investments in basic R\&D. Extending this logic, I hypothesize that increased internal R\&D will complement acquisitions for firms with high absorptive capacity. This allows me to formulate the following hypothesis:

Hypothesis 3: For firms with high absorptive capacity, there will be a positive interaction between acquisitions and $R \& D$ investments in their joint effect on firm performance.

\section{$3 \quad$ Method}

\subsection{Data and sample}

In order to test the hypotheses, I collected data on companies that are in the S\&P 500 and the S\&P 
400 indexes. The choice of these companies was dictated by the following reasons. First, I wanted to test my theory on a comprehensive sample of firms from different industries. Previous studies on performance effects of alliances often concentrated on specific industries (e.g. [8, 22 and 18]). Concentration on one industry or a group of closely related industries may allow for better control of industry-specific factors; however, this control necessarily comes at the expense of generalizability of the results. In order to bring my sample selection in line with previous studies that also relied on a multi-industry sample, I chose industries "where alliances are considered an important part of firm strategy" [15, p.988]. Based on this logic, I retained firms from industries whose SIC codes started with $1,2,3,4$, and 7 . I excluded retail and wholesale firms which are not usually alliance- and R\&Dactive. I also excluded financial service companies such as banks and insurance companies because it may be difficult to compare their performance with the performance of non-financial firms. Financial firms also do not usually invest much in R\&D. I also excluded the companies with SIC codes starting with 8 because there were too few of those companies in the sample, making industry adjustment of the key variables difficult. These restrictions on the selection of companies resulted in the final sample size of 303 publicly-traded companies.

Performance data for the participating companies were collected over the period from 1998 to 2013. Alliance data were collected in the period from 1998 to 2009. The source of alliance participation data was the SDC Platinum database [15, 24]. The source of data on acquisitions, R\&D investments, performance data, and control variables was Compustat.

\subsection{Dependent variables: firm performance}

One of the goals of this paper was to examine medium-term firm performance as the dependent variable. Alliances, acquisitions, and R\&D are likely to have a delayed effect on firm performance. In addition, measuring firm performance with a lag of one year (e.g. [23, 24]) may create spurious effects because of random fluctuations in annual performance data [32]. This is why I chose to measure performance as the average over four years starting with the year when the sizes of the alliance, acquisition, and $R \& D$ portfolios were measured [13]. For example, return on assets (ROA) was measured as the average of a firm's ROA in years $t, t+1, t+2$, and $t+3$. After computing the averages of the chosen performance indicators as described, I adjusted them for the industry averages by subtracting the mean of each indicator for the 1-digit SIC code that the focal firm belonged to.

There are different indicators that can be used to measure firm performance. A principal components analysis of my data showed that return on assets (ROA) and return on invested capital (ROIC) were associated with the first factor, return on sales (ROS) and sales growth were associated with the second factor (these indicators were negatively correlated), and assets growth and market-to-book (MTB) value were associated with the third factor. I included ROA, sales growth, and MTB as dependent variables that represented three distinct dimensions of firm performance that corresponded to profitability, growth, and market performance.

\subsection{Independent variables: alliance participa- tion, acquisitions, and $R \& D$ investments}

Previous researchers have referred to alliance portfolios [23, 13 and 36] as a measure of alliance participation. Firms can learn from engaging in multiple alliances over time [10, 11 and 37]. Firms may use multiple simultaneous alliances to fill the voids in their knowledge and to complement one another. Also, alliance participation numbers can exhibit volatility over time. Because of this, I computed the size of a firm's alliance portfolio as the total number of alliances that the focal firm entered in years $t-2$, $\mathrm{t}-1$, and $\mathrm{t}$. I used the natural $\log$ transformation to correct the highly skewed nature of the distribution of alliance portfolio sizes. I adjusted the alliance portfolios for the industry by subtracting the average portfolio size for each 1-digit SIC code.

Acquisition portfolios were calculated in a similar fashion. I summed up the dollar amounts of all acquisitions that the focal firm made during the years $\mathrm{t}-2, \mathrm{t}-1$, and $\mathrm{t}$. I adjusted the resulting size of the ac- 
quisition portfolio by subtracting the average for the 1-digit SIC code.

$R \& D$ investments were converted to $R \& D$ intensity by dividing $R \& D$ investments by the total sales of the focal firm for each year. Then I averaged the R\&D intensity for each firm over the three years $\mathrm{t}-2, \mathrm{t}-1$, and $\mathrm{t}$.

I used industry-adjusted R\&D intensity to distinguish between firms with high vs. low absorptive capacity. I also used industry-adjusted $R \& D$ intensity as an independent variable in the model. This dual use of $R \& D$ intensity is consistent with the approach taken by Cassiman and Veugelers [3] who studied complementarities between R\&D and technology acquisitions in the high-R\&D and low-R\&D subsamples separately. Using three-way interactions (another possible way of controlling for R\&D levels) would not be helpful because (1) two out of three relationships are two-way interactions between $R \& D$ and another variable; (2) my results show that the effect of R\&D in the alliances-acquisitions interactions is non-linear: there is no interaction in the lowR\&D subsample and a negative interaction in the high-R\&D subsample. These considerations suggest that splitting the sample into high-R\&D and low$R \& D$ firms is the more fruitful approach.

\subsection{Control variables}

I used the following variables as controls: year dummies, firm size (the natural logarithm of the average of sales, assets, and total liabilities), ROA,
ROE, ROIC, assets growth, solvency (the natural logarithm of the ratio of cash and short-term investments to total liabilities), and market-to-book. I did not use industry dummies in the model because fixed effects estimation does not allow parameters that are constant for each specific firm [35]. Instead, I adjusted each control variable by subtracting its mean for each 1-digit SIC code from the observed raw values. Thus, all variables in the model except for year dummies were industry-adjusted.

\subsection{Statistical technique}

In order to test the hypotheses, I ran fixed effects panel linear models. The choice of fixed effects over random effects was dictated by the following reasons. First, fixed effects estimation allows researchers to capture the effects of unobserved heterogeneity among firms. Firms differ in their resources and capabilities which could be difficult to measure. Fixed effects estimation allows those unobserved firm characteristics to be correlated with the error term. Second, the Hausman tests showed that the random effects models were inconsistent. This result suggested that there were significant firm-specific effects and therefore the fixed-effects estimator was necessary.

\section{$4 \quad$ Results}

Tables 1 and 2 provide the descriptive statistics and the correlations for the variables in the model.

Table 1. Descriptive statistics

\begin{tabular}{|l|r|r|r|r|r|}
\hline & \multicolumn{1}{|c|}{$\mathbf{N}$} & Minimum & Maximum & Mean & Std. Deviation \\
\hline Average ROA 4 years & 5015 & -2.05 & 0.39 & .0000 & 0.09942 \\
\hline Average MTB 4 years & 4899 & -2.21 & 23.56 & .0000 & 1.42545 \\
\hline Average Sales Growth 4 years & 5015 & -0.54 & 3.36 & .0000 & 0.19532 \\
\hline Log(Alliance Portfolio) & 4295 & -1.49 & 4.57 & .0000 & 1.04559 \\
\hline Acquisitions Portfolio & 3911 & -2520.22 & 43278.07 & .0000 & 2415.99815 \\
\hline R\&D intensity & 4716 & -0.13 & 5.58 & .0000 & 0.18764 \\
\hline Firm size & 6825 & -5.98 & 5.17 & .0000 & 1.52445 \\
\hline Log(Solvency) & 6826 & -0.49 & 2.41 & .0000 & 0.36702 \\
\hline Assets Growth & 6399 & -1.00 & 54.94 & .0000 & 1.14586 \\
\hline ROA & 6845 & -2.97 & 1.09 & .0000 & 0.12167 \\
\hline ROE & 6845 & -34.39 & 141.45 & .0000 & 2.39823 \\
\hline ROIC & 6845 & -13.86 & 5.69 & .0000 & 0.30536 \\
\hline MTB & 6672 & -2.79 & 102.12 & .0000 & 2.74135 \\
\hline
\end{tabular}


Table 2. Correlations

\begin{tabular}{|l|l|c|c|c|c|c|c|c|c|c|c|c|c|c|}
\hline & & $\mathbf{1}$ & $\mathbf{2}$ & $\mathbf{3}$ & $\mathbf{4}$ & $\mathbf{5}$ & $\mathbf{6}$ & $\mathbf{7}$ & $\mathbf{8}$ & $\mathbf{9}$ & $\mathbf{1 0}$ & $\mathbf{1 1}$ & $\mathbf{1 2}$ & $\mathbf{1 3}$ \\
\hline $\mathbf{1}$ & $\begin{array}{l}\text { Average } \\
\text { ROA }\end{array}$ & 1 & & & & & & & & & & & & \\
\hline $\mathbf{2}$ & $\begin{array}{l}\text { Average } \\
\text { MTB }\end{array}$ & $.174^{* *}$ & 1 & & & & & & & & & & & \\
\hline $\mathbf{3}$ & $\begin{array}{l}\text { Average } \\
\text { Sales Growth }\end{array}$ & $-.036^{*}$ & $.036^{*}$ & 1 & & & & & & & & & & \\
\hline $\mathbf{4}$ & $\begin{array}{l}\text { Log (Alliance } \\
\text { Portfolio) }\end{array}$ & -.021 & $-.052^{* *}$ & -.020 & 1 & & & & & & & & & \\
\hline $\mathbf{5}$ & Acquisitions & -.012 & $-.116^{* *}$ & -.009 & $.395^{* *}$ & 1 & & & & & & & & \\
\hline $\mathbf{6}$ & $\begin{array}{l}\text { R\&D } \\
\text { intensity }\end{array}$ & $-.257^{* *}$ & $.195^{* *}$ & $.046^{* *}$ & .034 & -.037 & 1 & & & & & & & \\
\hline $\mathbf{7}$ & Firm size & .017 & $-.382^{* *}$ & -.027 & $.557^{* *}$ & $.490^{* *}$ & $-.224^{* *}$ & 1 & & & & & & \\
\hline $\mathbf{8}$ & $\begin{array}{l}\text { Log } \\
\text { (Solvency) }\end{array}$ & -.008 & $.508^{* *}$ & .002 & -.014 & $-.108^{* *}$ & $.325^{* *}$ & $-.373^{* *}$ & 1 & & & & & \\
\hline $\mathbf{9}$ & $\begin{array}{l}\text { Assets } \\
\text { Growth }\end{array}$ & $-.266^{* *}$ & $.079^{* *}$ & .003 & .006 & -.024 & $.090^{* *}$ & $-.084^{* *}$ & $.114^{* *}$ & 1 & & & & \\
\hline $\mathbf{1 0}$ & ROA & $.365^{* *}$ & $.143^{* *}$ & -.005 & $-.032^{*}$ & .000 & $-.251^{* *}$ & $.057^{* *}$ & $.043^{* *}$ & $-.045^{* *}$ & 1 & & & \\
\hline $\mathbf{1 1}$ & ROIC & $.216^{* *}$ & $.096^{* *}$ & -.003 & $-.030^{*}$ & .002 & $-.159^{* *}$ & $.045^{* *}$ & -.014 & -.023 & $.587^{* *}$ & 1 & & \\
\hline $\mathbf{1 2}$ & ROE & $.035^{*}$ & -.005 & -.005 & -.002 & -.002 & $-.047^{* *}$ & $.036^{* *}$ & -.022 & -.007 & $.043^{* *}$ & $.044^{* *}$ & 1 & \\
\hline $\mathbf{1 3}$ & MTB & .007 & $.537^{* *}$ & .001 & .009 & $-.063^{* *}$ & $.110^{* *}$ & $-.236^{* *}$ & $.409^{* *}$ & $.167^{* *}$ & $.134^{* *}$ & $.077^{* *}$ & .003 & 1 \\
\hline
\end{tabular}

Table 3 presents the results of hypothesis testing on the high-R\&D subsample. Each model includes year dummies (not shown). The hypotheses were tested using the fixed-effects estimator for the panel data. Table 3 (models 1-9) presents the results for the high-R\&D subsample (firms with the 3-year R\&D portfolio equal to or greater than the mean for the industry).

Table 3. Results of fixed effects regressions; high absorptive capacity subsample; unstandardized coefficients are reported

\begin{tabular}{|l|l|l|l|l|}
\hline $\begin{array}{c}\text { Independent } \\
\text { variables }\end{array}$ & $\begin{array}{c}\text { Hypothesis } \\
\text { (predicted sign) }\end{array}$ & $\begin{array}{c}\text { DV: Average } \\
\text { ROA }\end{array}$ & $\begin{array}{c}\text { DV: Average } \\
\text { MTB }\end{array}$ & $\begin{array}{c}\text { DV: Average } \\
\text { Sales Growth }\end{array}$ \\
\hline Firm size & & $-0.081^{* * *}$ & $-0.599^{* * *}$ & $-0.134^{* * *}$ \\
\hline ROE & & 0.001 & 0.003 & -0.001 \\
\hline ROIC & & $-0.037^{* * *}$ & -0.047 & -0.007 \\
\hline MTB & & 0.120 & & 0.004 \\
\hline Log(Solvency) & $-0.028^{*}$ & -0.173 & -0.003 \\
\hline Assets Growth & & $-0.023^{* * *}$ & -0.025 & 0.002 \\
\hline
\end{tabular}


Table 3. Results of fixed effects regressions; high absorptive capacity subsample; unstandardized coefficients are reported (cont.)

\begin{tabular}{|c|c|c|c|c|}
\hline Log(Alliance Portfolio) & & $0.015^{*}$ & -0.062 & -0.010 \\
\hline Acquisitions Portfolio & & $0.00003 *$ & 0.00004 & $-0.00008^{* * *}$ \\
\hline R\&D intensity & & 0.006 & 0.187 & $0.406^{* * *}$ \\
\hline $\begin{array}{l}\text { Log(Alliance Portfolio) x Acquisi- } \\
\text { tions Portfolio }\end{array}$ & $\begin{array}{l}\text { H1 } \\
(-)\end{array}$ & $-0.000007 *$ & $-0.0001 * * *$ & $0.00001 *$ \\
\hline $\begin{array}{l}\text { Log(Alliance Portfolio) } x \\
\text { R\&D intensity }\end{array}$ & $\begin{array}{l}\mathrm{H} 2 \\
(-)\end{array}$ & $-0.048^{*}$ & -0.059 & $-0.078^{*}$ \\
\hline $\begin{array}{l}\text { Acquisitions Portfolio } \mathrm{x} \\
\text { R\&D intensity }\end{array}$ & $\begin{array}{l}\mathrm{H} 3 \\
(+)\end{array}$ & $0.00003 *$ & $0.00004 * * *$ & $0.0002 * * *$ \\
\hline Adj. R-Squared & & 0.186 & 0.275 & 0.328 \\
\hline F-statistic & & $\begin{array}{l}10.6543 \text { on } 21 \\
\text { and } 780 \mathrm{DF}\end{array}$ & $\begin{array}{l}18.9627 \text { on } 20 \\
\text { and } 776 \mathrm{DF}\end{array}$ & $\begin{array}{l}23.9226 \text { on } 21 \\
\text { and } 777 \mathrm{DF}\end{array}$ \\
\hline
\end{tabular}

$*: \mathrm{p}<0.05 ; * *: \mathrm{p}<0.01 ; * * * \mathrm{p}<0.001$

Hypothesis 1 predicted a negative interaction coefficient between the alliance portfolio and the acquisition portfolio in the high-R\&D subsample. This interaction coefficient is negative and significant in the Average ROA model and in the Average MTB model, indicating that for both average ROA and average market-to-book, alliances and acquisitions acted as substitutes, worsening the performance effects of each other. These results support Hypothe- sis 1. However, in the Average Sales Growth model, the interaction coefficient between alliances and acquisitions was positive and significant, indicating that alliances and acquisitions acted as complements in their joint effect on average sales growth. This result is counter to the predictions of Hypothesis 1 .

Figures 1, 2, and 3 plot the interaction effects to illustrate Hypothesis 1.

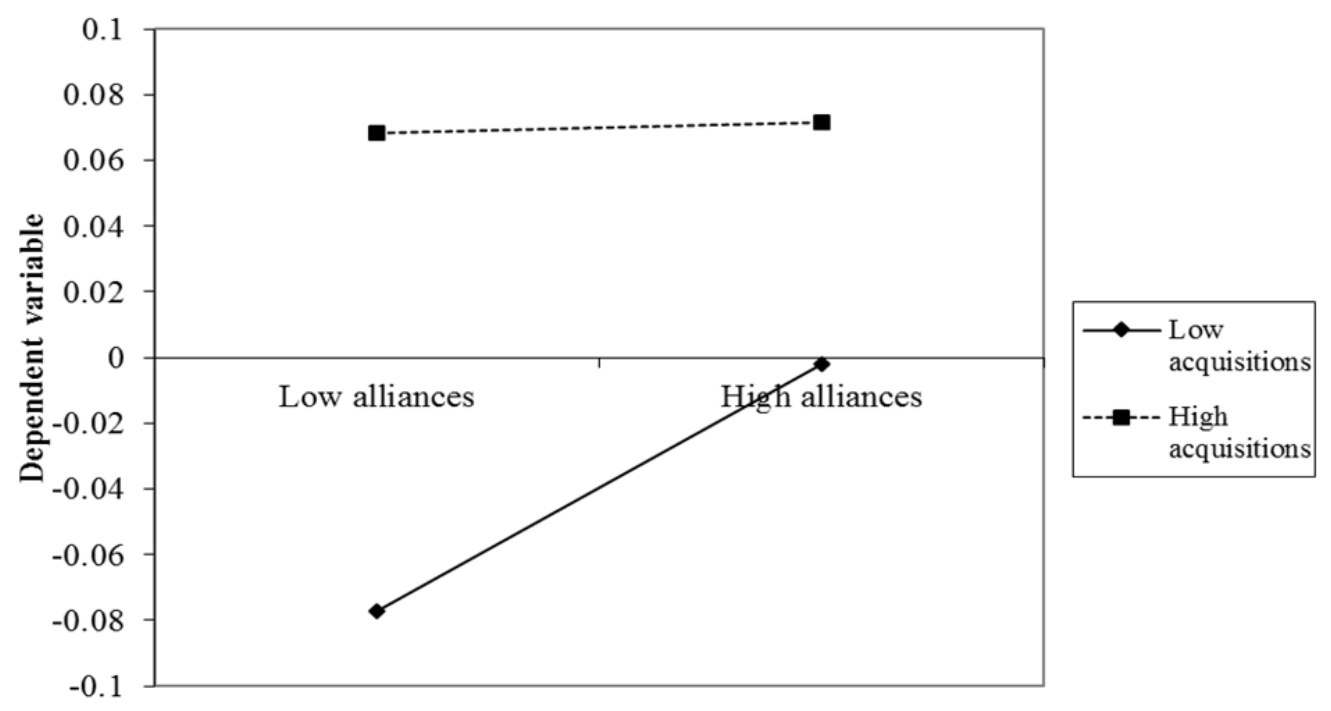

Figure 1. Interaction between alliances and acquisitions; DV - average ROA (demeaned) over 4 years 


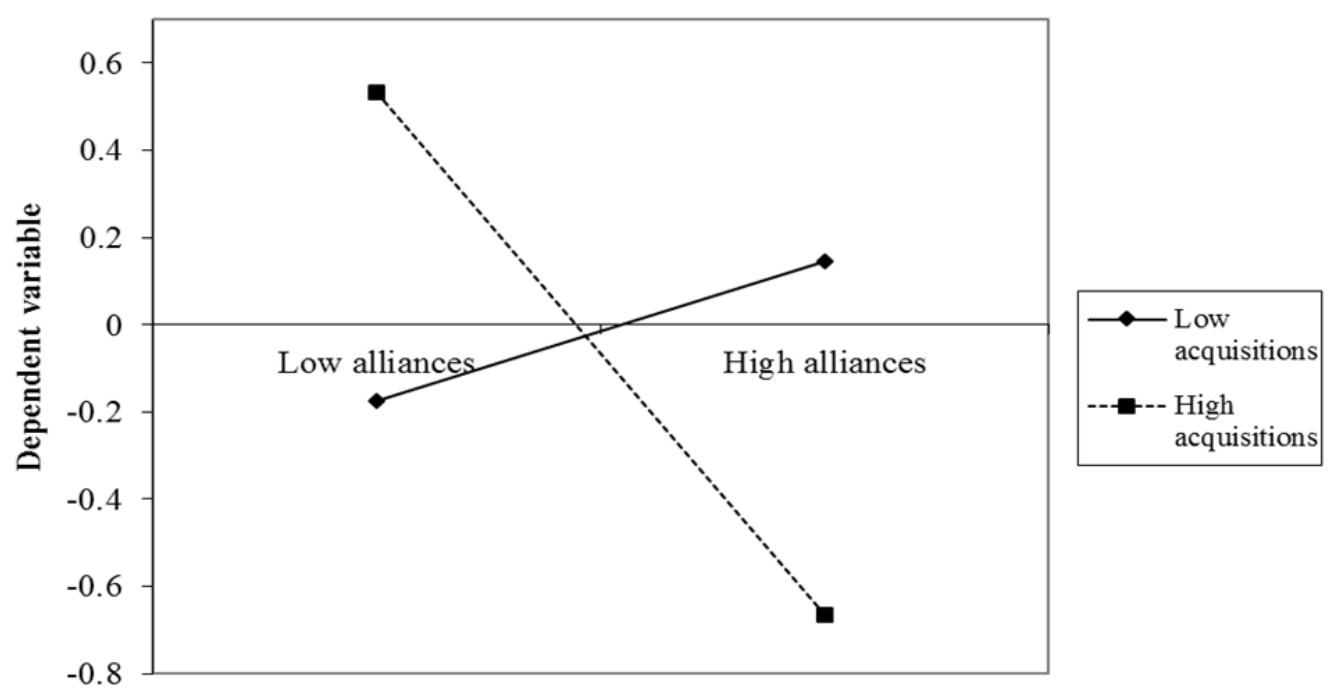

Figure 2. Interaction between alliances and acquisitions;

DV - average MTB (demeaned) over 4 years

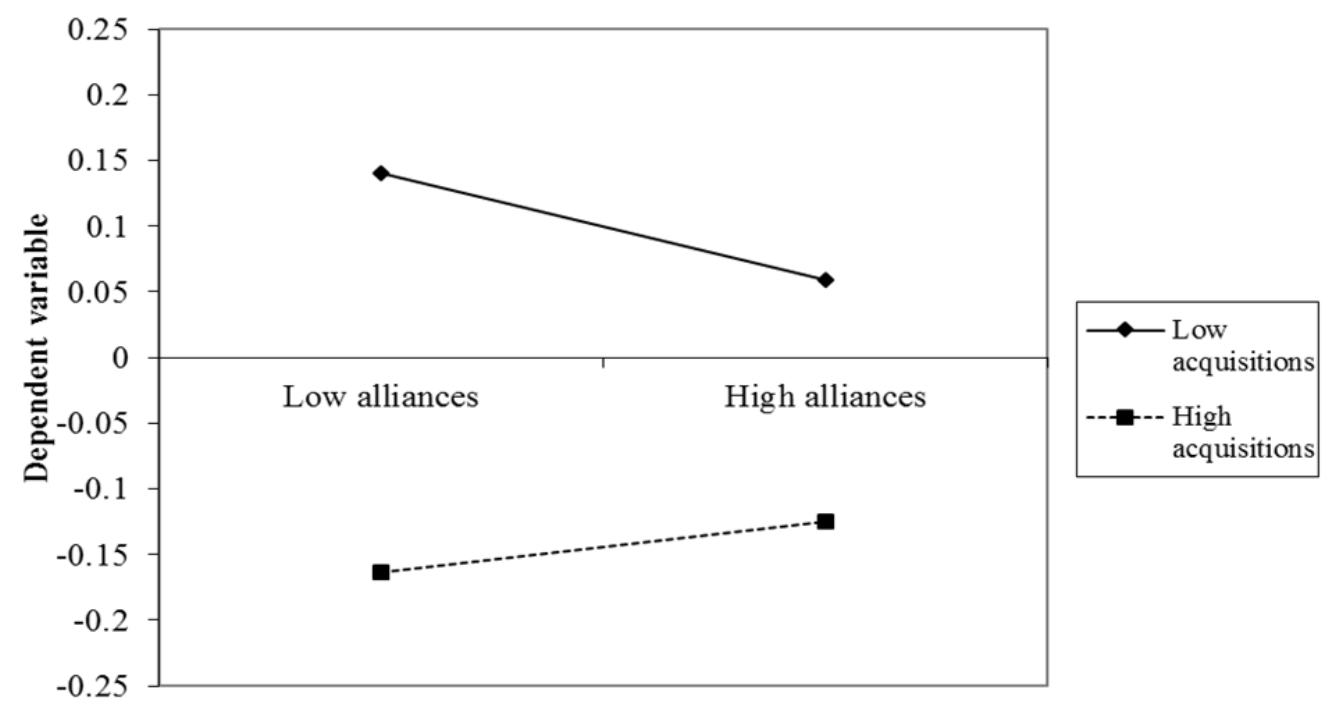

Figure 3. Interaction between alliances and acquisitions; DV - average sales growth for 4 years (demeaned)

Hypothesis 2 predicted a negative interaction coefficient between the alliance portfolio and the $R \& D$ portfolio in the high R\&D subsample. Model 3 (average ROA) and Model 9 (average sales growth) both show a negative interaction coefficient between the alliance portfolio and $R \& D$ portfolio, indicating that alliance and $\mathrm{R} \& \mathrm{D}$ portfolios acted as substitutes in their joint effects on average ROA and average sales growth. Model 6 shows no interaction between the alliance portfolio and $R \& D$ portfolio in their joint effect on MTB. These results provide partial support of Hypothesis 2.

Figures 4 and 5 plot the interactions that support Hypothesis 2. 


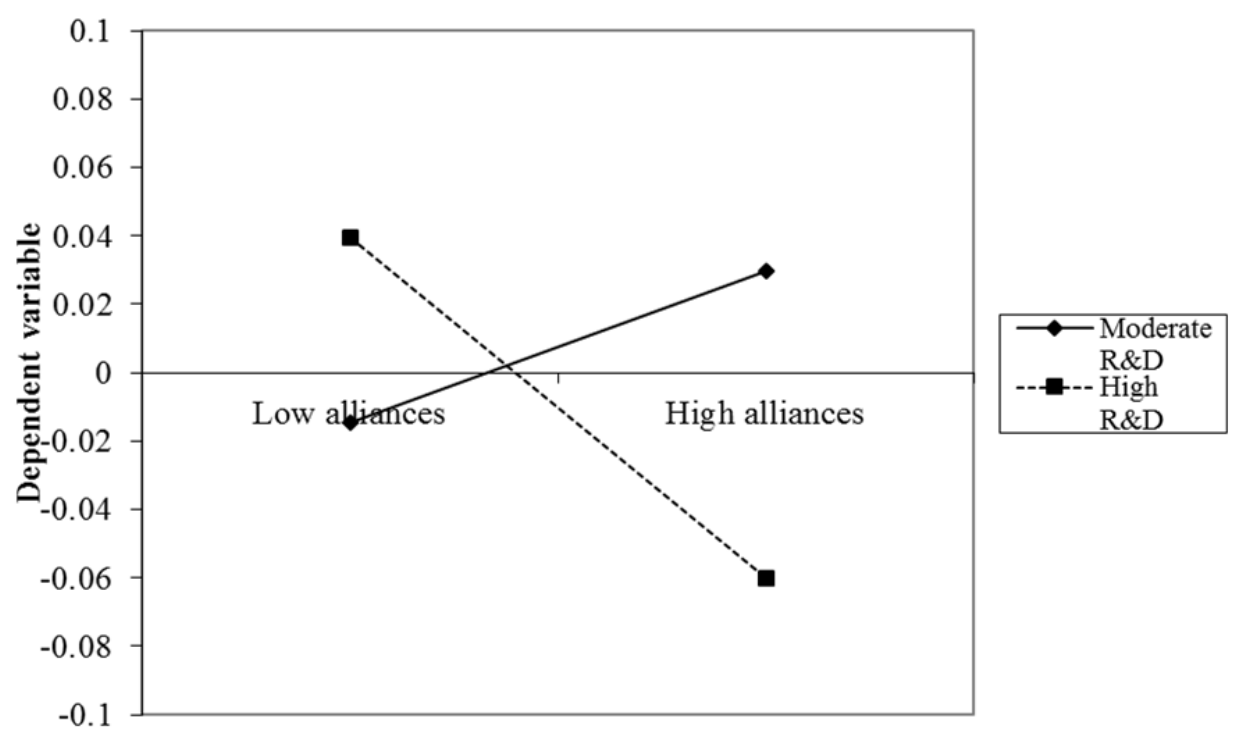

Figure 4. Interaction between alliances and R\&D; DV - Average ROA (demeaned) over 4 years

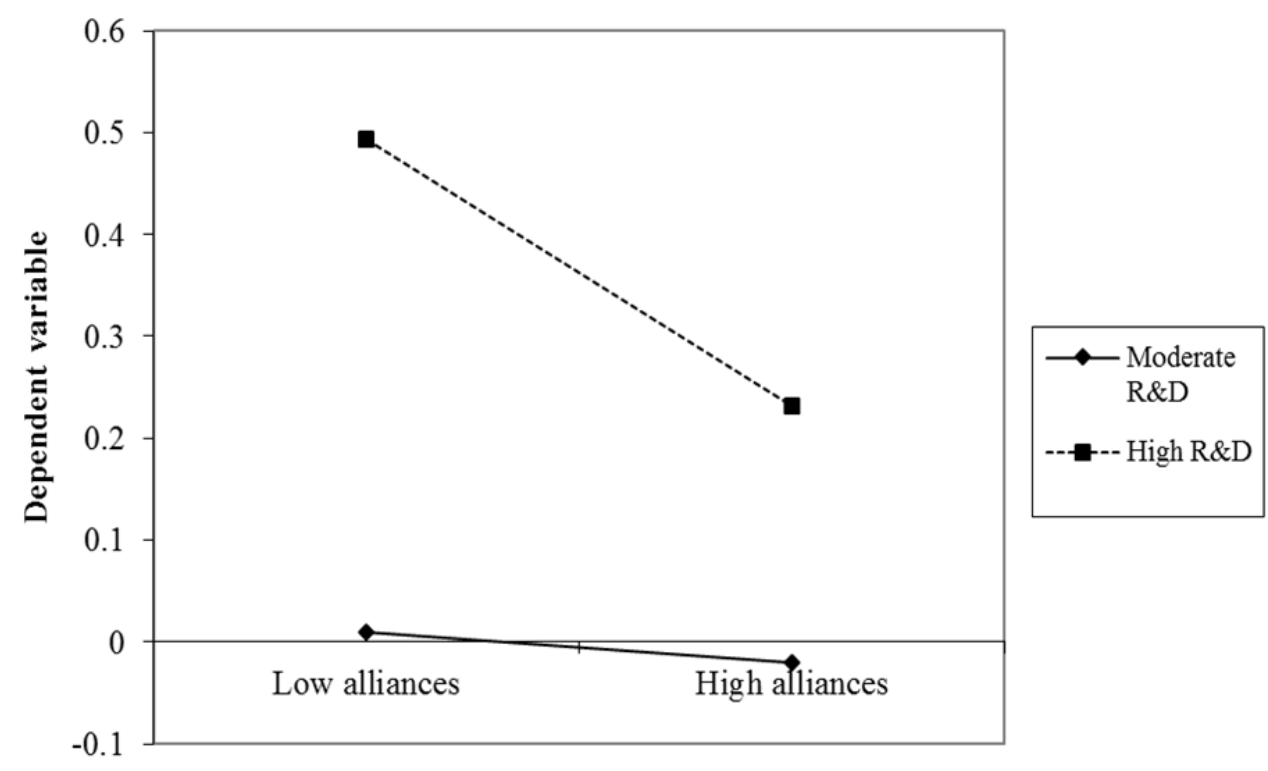

Figure 5. Interaction between alliances and R\&D; DV - average sales growth over 4 years (demeaned)

Hypotheses 3 predicted a positive interaction coefficient between the acquisition portfolio and the R\&D portfolio in the high R\&D subsample. Model 3 (average ROA), Model 6 (average MTB), and Model 9 (average sales growth) all show positive and significant interaction coefficients between acquisition portfolios and R\&D portfolios. These results indicate that acquisitions and $\mathrm{R} \& \mathrm{D}$ investments acted as complements in their joint effect on all three performance metrics. These results provide strong support for Hypothesis 3. 
Figures 6, 7, and 8 plot the interactions between each support for Hypothesis 3. pair of the independent variables. They provide clear
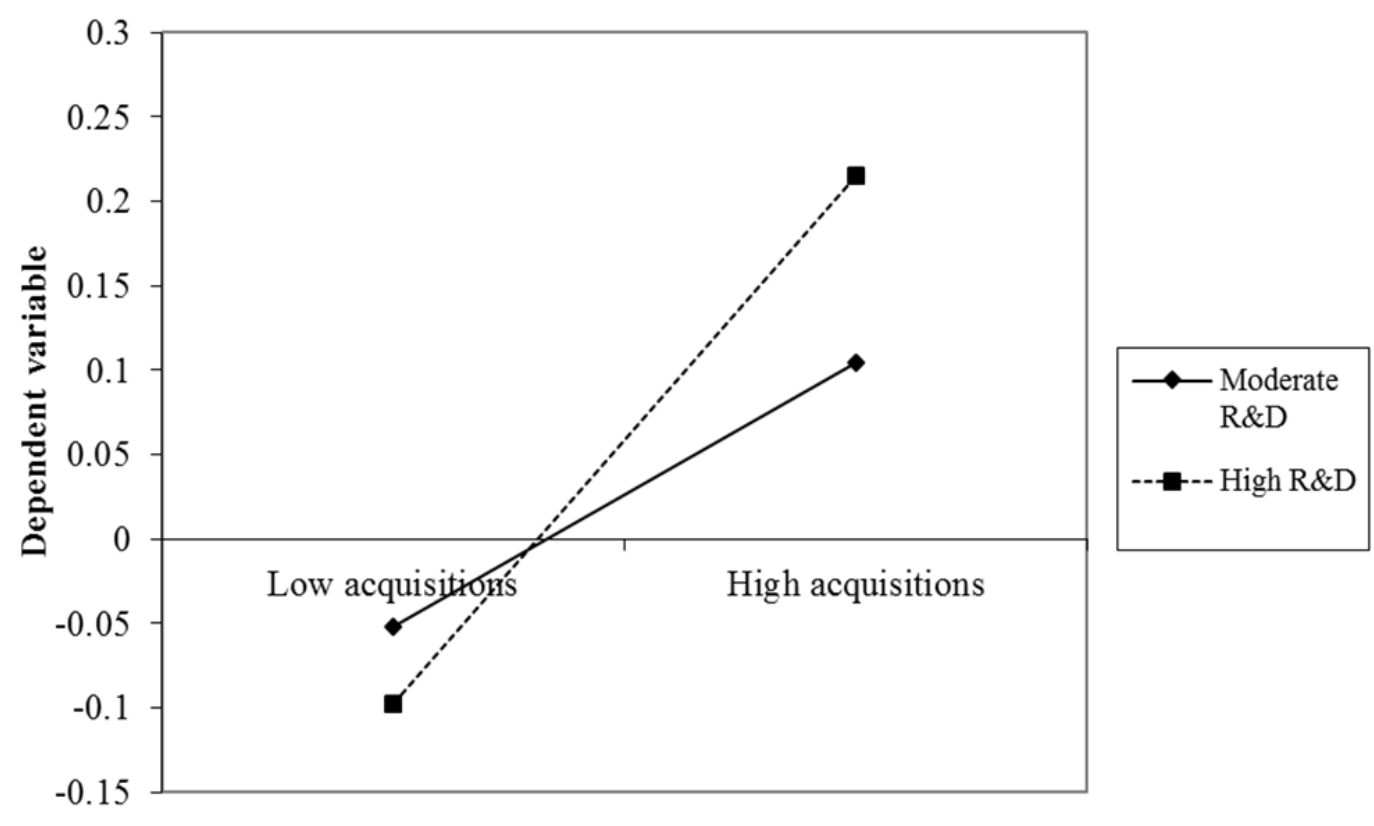

Figure 6. Interaction between acquisitions and R\&D;

DV - average ROA (demeaned) over 4 years

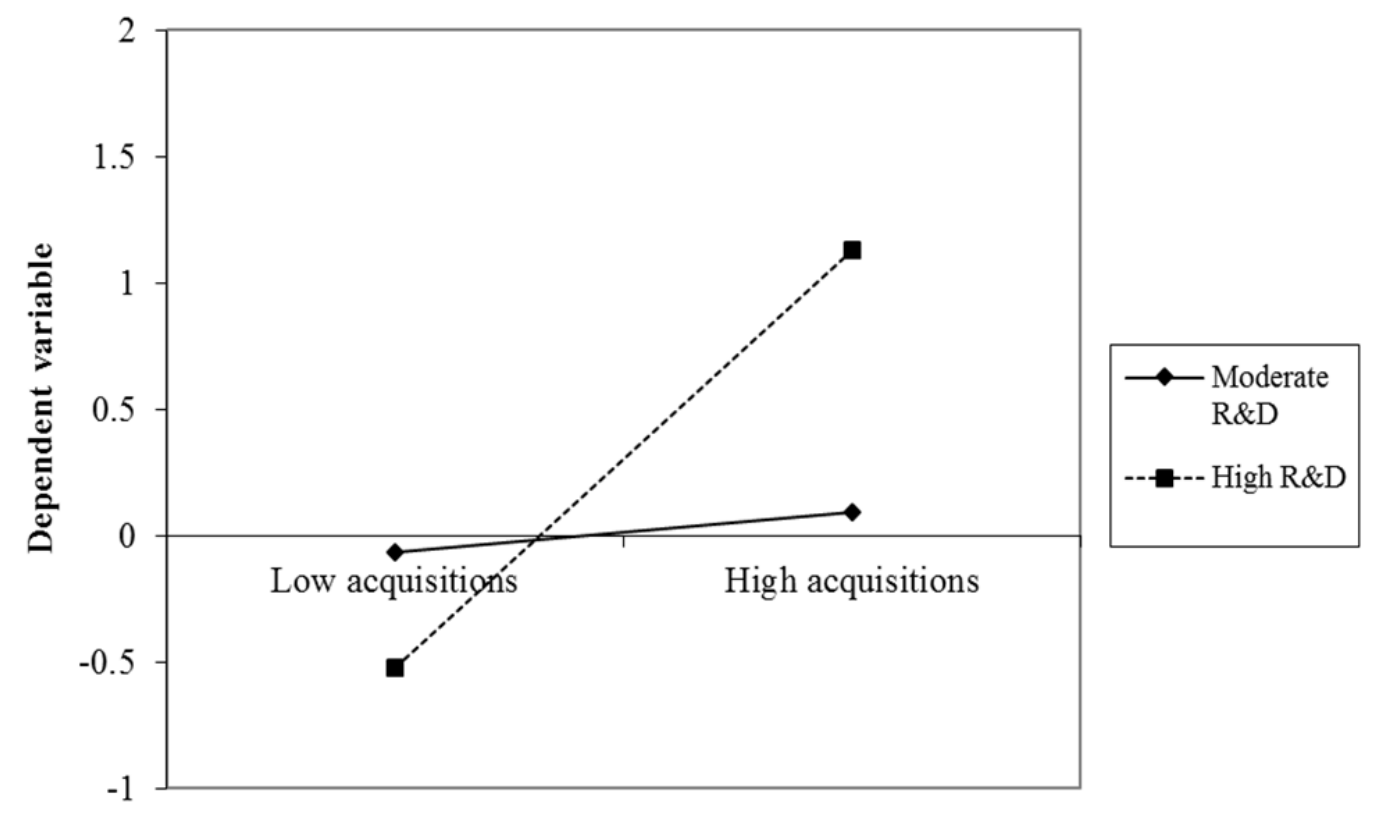

Figure 7. Interaction between acquisitions and $R \& D$; DV - average MTB over 4 years (demeaned) 


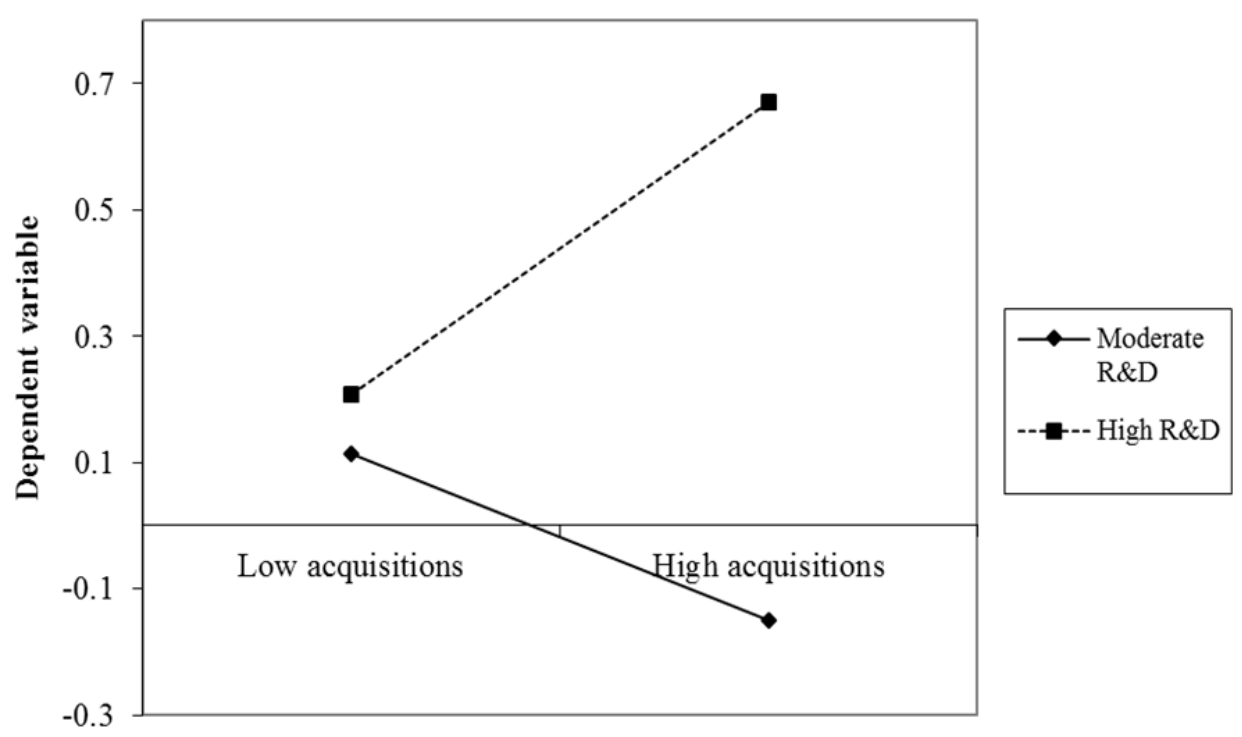

Figure 8. Interaction between acquisitions and R\&D;

DV - sales growth averaged over 4 years (demeaned)

\section{Discussion}

The overall goal of this paper was to investigate the possible interactions among alliances, acquisitions, and $R \& D$ investments in their joint effects on firm performance. The results indicate that firms with high R\&D investments and therefore high absorptive capacity find that alliances and acquisitions act as substitutes when average ROA, market-to-book, and sales growth over the next 4 years are considered as the dependent variable. However, the specific joint effects of alliances and acquisitions are different enough to warrant separate treatment.

\subsection{Theoretical significance}

The importance of this study is in suggesting the critical role of absorptive capacity in determining the optimal mix of alliances, acquisitions, and additional internal R\&D investments. Low-R\&D firms characterized by low absorptive capacity may choose any combination of the sizes of alliance and acquisition portfolios depending on their needs as long as they stick to allying with and acquiring relatively low-tech companies possessing significant amounts of tangible resources. High-R\&D firms possessing significant absorptive capacity will maximize profitability if they emphasize acquisitions and high inter- nal R\&D investments and de-emphasize alliances as part of their strategy. The same recommendation could be made to high-R\&D firms if their goal is to maximize their market-to-book value, which could be used to predict expected long-term firm performance. Finally, high-R\&D firms that aim to increase sales should also invest heavily in additional R\&D and complement that with an active program of acquisitions.

One paradoxical finding of this study is the low importance of alliances for improving high-R\&D firms' performance. High internal R\&D investments may create a false sense of power and ability to learn from others. High-R\&D firms may still find it difficult to learn from their alliance partners, especially if there is significant difference between the knowledge bases of the focal firm and its partners. Also, higher R\&D investments may increase a firm's absorptive capacity up to a point. Additional R\&D investments may result in greater specialization of a firm's knowledge, which may be less useful in trying to absorb other companies' knowledge. Previous studies found that firms often derive positive performance benefits from alliance participation $[1,26]$. Other studies found that the effect of alliance participation on performance was either zero or contingent on other factors [30, 24 and 13]. 
The results reported in this paper differ from those in previous studies in a number of important aspects. First, the present study uses multiple industries. Second, the present study uses three different measures of performance that are routinely used by executives and investors to evaluate firm performance: profitability, market valuation, and sales growth. Third, the present study takes a longer-term view of performance by averaging the performance indicators over 4 years. And finally, the present paper studies both large, established companies and smaller, younger firms. All of the firms in the sample were active at the time of the study. Many of those firms form the backbone of the U.S. economy. This is why I believe that the results reported here have both practical and theoretical significance. The overall insignificant performance effect of alliances could also be due to the fact that not all alliances are successful [27] and many of them fail. If firms do not properly learn how to select alliance partners successfully and how to manage the relationship in the alliance, an increased size of the alliance portfolio would be of little help.

This study shows that absorptive capacity affects the optimal strategy for firms. Firms with high absorptive capacity improve their performance by maximizing their internal $R \& D$ investments supplemented by acquisitions while firms with low absorptive capacity do not gain as much from any consistent strategy. This difference suggests that a high absorptive capacity may create competitive advantage by allowing the focal firm to choose the most appropriate acquisition targets and to integrate the knowledge successfully after the acquisition. The higher the firm's absorptive capacity, the more likely it is to recognize valuable knowledge before an acquisition and integrate it after the acquisition. Future researchers will be well advised to study acquisitions done by firms with high absorptive capacity and pay special attention to the choice of the targets. The results reported in this paper suggest that the focal firm will have the greatest advantage if it chooses targets that possess knowledge that the focal firm can evaluate and integrate. A possible future study will look at knowledge similarities and complementarities between the acquirer and the target as a predictor of performance consequences of acquisitions at the firm level.

\subsection{Limitations, assumptions, and directions for future research}

The most serious limitation of this study is the use of multiple industries. While I believe it is also one of the strengths of the study, it may create problems with pooling the results from very different industries. I took care to control for the industry when comparing firms from different industries. I adjusted all data for the industry by subtracting the mean for the 1-digit SIC code from each value. Another limitation of this study is the use of the largest publicly-traded U.S. firms. These results may not be applicable to small firms. Another limitation of this study is the exclusive use of U.S.-based firms. A potentially fruitful direction of future research is comparing the benefits of alliances, acquisitions, and $R \& D$ investments for firms from different countries.

Additional analyses (available from the author upon request) show that firms with low absorptive capacity did not demonstrate any of the relationships found in the high-absorptive-capacity subsample. This result suggests that firms with low absorptive capacity may pursue different goals when they enter alliances or make acquisitions. Such firms are unlikely to learn from their partners or targets and may primarily target economies of scale, increased efficiency, or access to new markets. Comparing and contrasting firms with different levels of absorptive capacity is a potentially fruitful avenue of future research.

\section{Conclusion}

This paper studied possible complementarities and substation effects between such strategic choices as alliances, acquisitions and $\mathrm{R} \& \mathrm{D}$ investments. The findings indicate that the firms' absorptive capacity affects the presence of the complementarities and substitution effects. Firms with high absorptive capacity exhibit substitution effects between alliances and acquisitions and between alliances and R\&D investments. Firms with high absorptive capacity also exhibit complementarities between acquisitions and $R \& D$ investments. 
These results were obtained on a sample of large and medium-sized U.S. companies. The results are robust to the use of different measures of performance: profitability, market-to-book value, and sales growth.

\section{$7 \quad$ References}

[1] Baum J.A.C., Calabrese T., Silverman B.S., 2000. Don't go it alone: Alliance network composition and startups' performance in Canadian biotechnology. Strategic Management Journal, Vol. 21, pp.267-294.

[2] Bergh D.D., 1997. Predicting divestiture of unrelated acquisitions: an integrative model of ex ante conditions. Strategic Management Journal, Vol. 18, pp.715-731.

[3] Cassiman B., Veugelers R., 2006. In search of complementarity in innovation strategy: internal R\&D and external knowledge acquisition. Management science, Vol. 52, pp.68-82.

[4] Cohen W.M., Levinthal D.A., 1990. Absorptive Capacity: A New Perspective on Learning and Innovation. Administrative Science Quarterly, Vol. 35, pp.128-152.

[5] Das S., Sen P.K., Sengupta S., 1998. Impact of strategic alliances on firm valuation. Academy of Management Journal, Vol. 41, pp.27-41.

[6] Das T.K., Teng B.-S., 2000. A Resource-Based Theory of Strategic Alliances. Journal of Management, Vol. 26, pp.31-61.

[7] de Leeuw T., Lokshin B., Duysters G., 2014. Returns to alliance portfolio diversity: The relative effects of partner diversity on firm's innovative performance and productivity. Journal of Business Research, Vol. 67, pp.1839-1849.

[8] Dussauge P., Garrette B., Mitchell W., 2004. Asymmetric performance: The market share impact of scale and link alliances in the global auto industry. Strategic Management Journal, Vol. 25, pp.701-711.

[9] Dyer J.H., Kale P., Singh H., 2004. When to Ally \& When to Acquire. Harvard Business Review, Vol. 82, pp.108-115.

[10] Gulati R., 1995. Does Familiarity Breed Trust? The Implications of Repeated Ties for Contractual Choice in Alliances. The Academy of Management Journal, Vol. 38, pp.85-112.
[11] Gulati R., 1998. Alliances and Networks. Strategic Management Journal, Vol. 19, pp.293-317.

[12] Heeley M.B., King D.R., Covin J.G., 2006. Effects of firm R\&D investment and environment on acquisition likelihood. Journal of Management Studies, Vol. 43, pp.1513-1535.

[13] Jiang R.J., Tao Q.T., Santoro M.D., 2010. Alliance portfolio diversity and firm performance. Strategic Management Journal, Vol. 31, pp.1136-1144.

[14] Kale P., Dyer J.H., Singh H., 2002. Alliance Capability, Stock Market Response, and LongTerm Alliance Success: The Role of the Alliance Function. Strategic Management Journal, Vol. 23, pp.747-767.

[15] Kale P., Singh H., 2007. Building firm capabilities through learning: The role of the alliance learning process in alliance capability and firmlevel alliance success. Strategic Management Journal, Vol. 28, pp.981-1000.

[16] Khanna T., Gulati R., Nohria N., 1998. The Dynamics of Learning Alliances: Competition, Cooperation, and Relative Scope. Strategic Management Journal, Vol. 19, pp.193-210.

[17] King D.R., Slotegraaf R.J., Kesner I., 2008. Performance Implications of Firm Resource Interactions in the Acquisition of R\&D-Intensive Firms. Organization Science, Vol. 19, pp.327340.

[18] Koka B.R., Prescott J.E., 2008. Designing alliance networks: The influence of network position, environmental change, and strategy on firm performance. Strategic Management Journal, Vol. 29, pp.639-661.

[19] Lahiri N., Narayanan S., 2013. Vertical integration, innovation, and alliance portfolio size: Implications for firm performance. Strategic Management Journal, Vol. 34, pp.1042-1064.

[20] Lane P.J., Lubatkin M., 1998. Relative absorptive capacity and interorganizational learning. Strategic Management Journal, Vol. 19, pp.461477.

[21] Lavie D., 2006. The competitive advantage of interconnected firms: An extension of the resource-based view. Academy of Management Review, Vol. 31, pp.638-658.

[22] Lavie D., 2007. Alliance portfolios and firm performance: A study of value creation and ap- 
propriation in the U.S. software industry. Strategic Management Journal, Vol. 28, pp.11871212.

[23] Lavie D., Miller S.R., 2008. Alliance portfolio internationalization and firm performance. $\mathrm{Or}$ ganization Science, Vol. 19, pp.623-646.

[24] Lin Z., Yang H., Arya B., 2009. Alliance partners and firm performance: resource complementarity and status association. Strategic Management Journal, Vol. 30, pp.921-940.

[25] Mowery D.C., Oxley J.E., Silverman B.S., 1998. Technological overlap and interfirm cooperation: implications for the resource-based view of the firm. Research Policy, Vol. 27, pp.507523.

[26] Oum T.H., Park J.H., Kim K., Yu C.Y., 2004. The effect of horizontal alliances on firm productivity and profitability: evidence from the global airline industry. Journal of Business Research, Vol. 57, pp.844-853.

[27] Park S.H., Ungson G.R., 2001. Interfirm Rivalry and Managerial Complexity: A Conceptual Framework of Alliance Failure. Organization Science, Vol. 12, pp.37-53.

[28] Reuer J.J., Lahiri N., 2014. Searching for Alliance Partners: Effects of Geographic Distance on the Formation of R\&D Collaborations. Organization Science, Vol. 25, pp.283-298.

[29] Singh H., Montgomery C.A., 1987. Corporate acquisition strategies and economic performance. Strategic Management Journal, Vol. 8, pp.377-386.
[30] Stettner U., Lavie D., 2014. Ambidexterity under scrutiny: Exploration and exploitation via internal organization, alliances, and acquisitions. Strategic Management Journal, Vol. 35, pp.1903-1929.

[31] Stuart T.E., 2000. Interorganizational alliances and the performance of firms: A study of growth and innovation rates in a high-technology industry. Strategic Management Journal, Vol. 21, pp.791-811.

[32] Tanriverdi H., 2006. Performance effects of information technology synergies in multibusiness firms. MIS Quarterly, pp.57-77.

[33] Tsai W., 2001. Knowledge transfer in intraorganizational networks: Effects of network position and absorptive capacity on business unit innovation and performance. Academy of Management Journal, Vol. 44, pp.996-1004.

[34] Vandaie R., Zaheer A., 2014. Surviving bear hugs: Firm capability, large partner alliances, and growth. Strategic Management Journal, Vol. 35, pp.566-577.

[35] Wooldridge J.M., 2010. Econometric analysis of cross section and panel data. MIT press

[36] Yamakawa Y., Yang H.B., Lin Z.A., 2011. Exploration versus exploitation in alliance portfolio: Performance implications of organizational, strategic, and environmental fit. Research Policy, Vol. 40, pp.287-296.

[37] Zollo M., Reuer J.J., Singh H., 2002. Interorganizational Routines and Performance in Strategic Alliances. Organization Science, Vol. 13, pp.701-713. 